\title{
JOANNA HELIOS
}

Uniwersytet Wrocławski

\section{ROLA DEONTOLOGII WETERYNARY JNEJ W OCHRONIE ZWIERZĄT I ICH PRAW}

\section{WPROWADZENIE}

Celem niniejszego szkicu jest zwrócenie uwagi na współczesną rolę deontologii weterynaryjnej, która w mojej ocenie powinna zabezpieczać dobro zwierząt i przyczyniać się do realizacji ich praw. Deontologia weterynaryjna określa zasady postępowania moralnego lekarzy weterynarii wobec zwierząt, ich właścicieli, innych lekarzy weterynarii, a także badań na zwierzętach. Zasady postępowania lekarza weterynarii muszą być zgodne z regułami kodeksu deontologicznego. W związku z powyższym celem wyodrębniono następujące grupy problemów:

— pojmowanie deontologii;

- odpowiedzialność zawodowa lekarza weterynarii, ze wskazaniem na odpowiedzialność odszkodowawczą i dyscyplinarną;

— rola Kodeksu Etyki Lekarza Weterynarii w ochronie prawnej zwierząt;

- tajemnica zawodowa lekarzy weterynarii.

\section{POJMOWANIE DEONTOLOGII}

Deontologia jest działem etyki, który koncentruje się na obowiązkach moralnych, np. etyce lekarskiej, normującej obowiązki moralne lekarza względem pacjentów i kolegów lekarzy. Termin ten został stworzony przez Jeremy’ego Benthama na określenie utylitarystycznej teorii powinności i zakłada jak najbardziej ogólną, a zarazem ścisłą znaczeniowo, wykładnię obowiązków dla danej jednostki i społeczeństwa. Obecnie deontologia definiowana jest jako zbiór powinności, obowiązków oraz wiążących się z nimi odpowiedzialności i zobowiązań. Dotyczy ona nie tylko społeczności zawodowej, ale także ludzi żyjących w określonych społecznościach. Jest ona praktyczną wykładnią moralnych obowiązków ludzi, 
adeptów zawodu, w przypadku lekarzy czy lekarzy weterynarii, spełnianych w odniesieniu do ich pacjentów oraz wspólnoty zawodowej.

Termin ,deontologia” został po raz pierwszy zastosowany w uchwalonym na X Zjeździe Lekarzy i Przyrodników Polskich (Lwów 1907) Kodeksie Deontologii Lekarskiej. Tą samą terminologią (deontologia lekarska) posłużył się związek lekarzy francuskich, uchwalając w 1945 r. przepisy postępowania dla swoich członków. Przewodnia idea etycznego postępowania każdego lekarza weterynarii zawarta jest w Kodeksie Etyki i Deontologii Weterynaryjnej, przyjętym na Krajowym Zjeździe Lekarzy Weterynarii. Deontologia próbuje przełożyć i zastosować w konkretnych przypadkach ogólnie przyjęte normy etyczne w odniesieniu do lekarzy weterynarii i podejmowanych przez nich działań. Obiektem jej zainteresowań są podstawowe pytania dotyczące: zabijania i okoliczności, w których jest ono akceptowalne; odpowiedzialności lekarskiej i jej konsekwencji, a także aspektów powstrzymywania się od wyrządzania szkody, w tym również lekarskiego Primum non nocere. Zasady postulowane przez deontologię znajdują odbicie w większości kodeksów prawa.

Dla unaocznienia owej zależności można posłużyć się zapisem polskiego Kodeksu Etyki Lekarskiej, w którym czytamy: „Zasady etyki lekarskiej wynikają z ogólnych norm etycznych" (art. 1). Etos lekarza jest ukonstytuowany przez wielość wartości przynależnych wykonywanym przez niego czynnościom, z których dwie nabierają zasadniczego znaczenia: kompetencja i odpowiedzialność. Wiedza i wiążąca się z nią kompetencja powinny mieć dla lekarza charakter wartości pozamoralnej, wręcz moralnie konstytutywnej, poza wszelką wątpliwością. Zgodnie z polskim Kodeksem Etyki Lekarskiej: „Powinnością każdego lekarza jest stałe uzupełnianie i doskonalenie swej wiedzy i umiejętności zawodowych” (art. 56). Kształcenie ustawiczne, w celu jak najlepszego wypełniania swojej zawodowej misji, powinno być właściwe również lekarzom weterynarii. Z punktu widzenia dzisiejszej medycyny, etyki oraz refleksji deontologicznej na plan pierwszy wysuwa się odpowiedzialność. To, co należy czynić, czyli odpowiedzialne korzystanie z posiadanej wiedzy i kompetencji, zdaje się być najważniejszą cechą powinności lekarza, kształtującą jego ethos.

Wyróżniane są cztery zasady etyki lekarskiej: nieszkodzenia, autonomii, dobroczynności i sprawiedliwości, które, jako wtórne, dają się sprowadzić do pojęcia działania odpowiedzialnego i kompetentnego. W literaturze analizującej zagadnienia etyki lekarskiej można wyróżnić trzy podstawowe nurty: etykę deontologiczną, kazuistyczną i problemową. Najważniejszą w zakresie powinności lekarza weterynarii będzie etyka deontologiczno-kodeksowa, tworząca system norm obowiązujących w świecie lekarskim, opierając się na ustaleniach samego środowiska lekarskiego. Źródeł kodeksowej etyki lekarskiej należy szukać w kulturze śródziemnomorskiej czasów legendarnego lekarza Hipokratesa (460-377 p.n.e.), jednocześnie nie zapominając o wcześniejszych dokonaniach w tej materii lekarzy Dalekiego Wschodu czy starożytnego Egiptu. W końcu w XX w. nastąpił dalszy 
rozwój nauki, zatarła się stopniowo granica między życiem a śmiercią, pojawiły się zagadnienia związane $\mathrm{z}$ aborcją, eutanazją, eksperymentami na ludziach i zwierzętach, manipulacjami genetycznymi, transplantologią, paternalizmem wobec pacjentów, zaniechaniem terapii i leczeniem paliatywnym. Jednakże etyka lekarska we wszystkich trzech nurtach, czyli kodeksowym, kazuistycznym i systematyczno-problemowym, jest i prawdopodobnie pozostanie jeszcze przez wiele lat próbą wypracowania norm moralnych, którymi powinien kierować się adept sztuki medycznej w swej powinności zawodowej ${ }^{1}$.

\section{ODPOWIEDZIALNOŚĆ ZAWODOWA LEKARZY WETERYNARII}

Z deontologią ściśle związane jest pojęcie odpowiedzialności zawodowej, która rozumiana jest jako odpowiedzialność za popełnienie przewinienia zawodowego. Stanowi ona szczególny rodzaj odpowiedzialności wynikający z przynależności do określonej grupy i ważnej dla społeczeństwa grupy zawodowej. Ustawa o odpowiedzialności zawodowej dotyczy szerokiej grupy zawodów medycznych - lekarzy, lekarzy dentystów, pielęgniarek i położnych, aptekarzy, ratowników medycznych, diagnostów laboratoryjnych, dietetyków, masażystów oraz lekarzy weterynarii ${ }^{2}$. Odpowiedzialność zawodowa, inaczej dyscyplinarna, dotycząca odpowiedzialności za przewinienia dokonane $\mathrm{w}$ związku $\mathrm{z}$ wykonywaniem danego zawodu, związana jest przede wszystkim z wolnymi zawodami, gdzie działania realizowane są na własne ryzyko i powinny być wykonywane z zachowaniem należytej staranności, gdyż związane są z dużym zaufaniem osób trzecich; dotykająca zawodów prawniczych i medycznych, stosuje się w dużej mierze do lekarzy weterynarii ${ }^{3}$. Pojęcie wolnego zawodu, dotyczące również lekarzy weterynarii, odnosi się do zawodu wykonywanego na podstawie odpowiedniego wykształcenia, samodzielnie, co nie znaczy, że indywidualnie, na własną odpowiedzialność, w sposób niezależny zawodowo, w celu oferowania usług intelektualnych lub koncepcyjnych $\mathrm{w}$ interesie klienta lub $\mathrm{w}$ interesie publicznym. Ważnymi cechami właściwego wykonywania wolnego zawodu są: misja wykonywania zawodu, przestrzeganie reguł deontologicznych, zapewnienie klientom tajemnicy zawo-

1 T. Ożóg, Podstawy deontologii i nowy status zwierząt, [w:] Historia weterynarii i deontologia, red. M. Janeczek et al., Warszawa 2012, s. 404-408.

2 T. Gawlik-Jakubczak, Odpowiedzialność prawna lekarza. Czesść 2, „Przegląd Urologiczny” 89, 2015, nr 1, http://www.przeglad-urologiczny.pl/artykul.php?2765\&print+1 (dostęp: 20 lutego 2016).

3 Ł.B. Pilarz, Odpowiedzialność zawodowa - postępowanie dyscyplinarne wobec lekarzy weterynarii, http://weterynarianews.pl/odpowiedzialnosc-zawodowa-postepowanie-dyscyplinarne-wo bec-lekarzy-weterynarii/ (dostęp: 18 lutego 2016). 
dowej i zaufania oraz ponoszenie szczególnej odpowiedzialności z racji sposobu wykonywania zlecenia ${ }^{4}$.

Podstawy prawne odpowiedzialności zawodowej lekarzy weterynarii zostały ustalone w Ustawie z 21 grudnia 1990 r. o zawodzie lekarza weterynarii i izbach lekarsko-weterynaryjnych (Dz.U. z 2009 r. Nr 93, poz. 767 ze zm.) ${ }^{5}$ oraz aktach wykonawczych do niej, przede wszystkim w Rozporządzeniu Ministra Rolnictwa i Gospodarki Żywnościowej z dnia 29 lipca 1993 r. w sprawie postępowania dotyczącego odpowiedzialności zawodowej lekarzy weterynarii (Dz.U. z 1993 r. $\mathrm{Nr} 79$, poz. 371). Lekarzy weterynarii dotyczą także: Ustawa z 18 grudnia 2003 r. o zakładach leczniczych dla zwierząt (Dz.U. z 2004 r. Nr 11, poz. 95 z późn. zm.), Kodeks Etyki Lekarza Weterynarii (Uchwała nr 3/2008/VII Nadzwyczajnego VII Krajowego Zjazdu Lekarzy Weterynarii z 26 stycznia 2008 r.), Rozporządzenie Ministra Spraw Wewnętrznych i Administracji z 26 sierpnia 1998 r. w sprawie zasad i warunków wyłapywania bezdomnych zwierząt (Dz.U. z 1998 r. Nr 116, poz. 753 z późn. zm.). Są to najważniejsze akty prawne dotyczące sytuacji prawnej lekarzy weterynarii, określające ich odpowiedzialność zawodową, w tym odpowiedzialność za wykonywanie przez technika weterynarii czynności przewidzianych prawnie dla lekarza weterynarii ${ }^{6}$, stosunek do zwierząt, także do ich właścicieli, podstawy prawne wykonywania zawodu, zasady prowadzenia lecznic dla zwierząt/prywatnej praktyki lekarza weterynarii.

Ustawa o zawodzie lekarza weterynarii i izbach lekarsko-weterynaryjnych z dnia 21 grudnia 1990 r. wskazuje katalog zagadnień, którymi w codziennej praktyce zajmuje się lekarz weterynarii. Zgodnie z ustawą wykonywanie zawodu lekarza weterynarii polega na ochronie zdrowia zwierząt oraz weterynaryjnej ochronie zdrowia publicznego i środowiska, a w szczególności:

1) badaniu stanu zdrowia zwierząt;

2) rozpoznawaniu i zwalczaniu chorób zwierząt oraz zapobieganiu im;

3) leczeniu zwierząt oraz wykonywaniu zabiegów chirurgicznych;

4) wydawaniu opinii i orzeczeń lekarsko-weterynaryjnych;

4 A. Krasnowolski, Zawody zaufania publicznego, zawody regulowane oraz wolne zawody. Geneza, funkcjonowanie i aktualne problemy (Opracowania tematyczne OT-625. Biuro Analiz i Dokumentacji. Zespół Analiz i Opracowań Tematycznych), Warszawa 2013, nr 11, s. 3 n.

${ }^{5}$ Należy mieć także na uwadze prawo unijne. Państwa członkowskie wymagają od osób pragnących rozpocząć wykonywanie zawodu lekarza weterynarii, aby posiadały odpowiednie dokumenty. Co istotne, osoba, która chce rozpocząć wykonywanie zawodu lekarza weterynarii, obok wymienionych w unijnej dyrektywie dokumentów, musi wylegitymować się m.in. dostateczną znajomością zachowania się zwierząt i ich ochrony. Dyrektywa Rady z dnia 18 grudnia 1978 r. dotycząca koordynacji przepisów ustawowych, wykonawczych i administracyjnych w zakresie działalności lekarza weterynarii, 78/1027/EWG.

${ }^{6}$ P. Listos, Odpowiedzialność zawodowa lekarza. Wykonywanie przez technika weterynarii czynności przewidzianych prawnie dla lekarza weterynarii, „Weterynaria w Praktyce” 8, 2011, nr 1-2, s. 76-77. 
5) badaniu zwierząt rzeźnych, mięsa i innych produktów pochodzenia zwierzęcego;

6) sprawowaniu czynności związanych z nadzorem weterynaryjnym nad obrotem zwierzętami oraz warunkami sanitarno-weterynaryjnymi miejsc gromadzenia zwierząt i przetwarzania produktów pochodzenia zwierzęcego;

7) badaniu i ocenie weterynaryjnej jakości pasz i pasz leczniczych oraz warunków ich wytwarzania i dystrybucji;

8) stosowaniu produktów leczniczych weterynaryjnych wydawanych z przepisu lekarza weterynarii;

9) wydawaniu recept na produkty lecznicze, z wyłączeniem produktów leczniczych weterynaryjnych, które będą stosowane u zwierząt ${ }^{7}$.

Wykonywanie przez lekarzy weterynarii czynności leczniczych stanowi istotną formę realizowania ochrony zwierząt. Najczęściej odbywa się to poprzez świadczenie usług z zakresu medycyny weterynaryjnej. W celu umożliwienia realizacji wspomnianego świadczenia prawodawca powołał do życia zakłady lecznicze dla zwierząt. Wedle Ustawy z 18 grudnia 2003 r. o zakładach leczniczych zakład leczniczy dla zwierząt stanowi placówkę ochrony zdrowia i dobrostanu zwierząt, wyposażoną w środki majątkowe, które stanowią pomieszczenia, aparatura oraz sprzęt, dostosowane do zakresu oraz charakteru świadczonych usług leczniczo-weterynaryjnych. Realizacja ochrony zwierząt w zakładach leczniczych wykonywana jest głównie przez osoby posiadające tytuł lekarza weterynarii. Ustawodawca dopuszcza do wykonywania czynności z zakresu świadczonych usług medyczno-weterynaryjnych w zakładach leczniczych dla zwierząt także osoby posiadające tytuł technika weterynarii. Zakres czynności personelu pomocniczego prawodawca w sposób szczegółowy określił we wskazanej ustawie. Realizacja ochrony zwierząt poprzez świadczenie usług weterynaryjnych w zakładach leczniczych dla zwierząt, z wyłączeniem weterynaryjnych laboratoriów diagnostycznych, może odbywać się w sposób kompleksowy, bez względu na formę zakładu leczniczego. Jednakże analiza zaleconych/nakazanych przez prawodawcę niezbędnych wymagań lokalowych, aparaturowych oraz dotyczących kwalifikacji zawodowych lekarzy weterynarii pełniących funkcje kierowników poszczególnych zakładów leczniczych pozwala stwierdzić, iż w sposób podstawowy ochrona weterynaryjna zwierząt jest realizowana $\mathrm{w}$ gabinetach weterynaryjnych, najszerzej w klinikach weterynaryjnych. Prawodawca, powołując do życia różne formy zakładów leczniczych dla zwierząt jako miejsce realizacji nakreślonej przepisami prawa ochrony zwierząt, przewidział też znaczącą rolę samorządu lekarsko-weterynaryjnego w sprawowaniu pieczy nad właściwym funkcjonowaniem ${ }^{8}$.

7 Ustawa z dnia 21 grudnia 1990 r. o zawodzie lekarza weterynarii i izbach lekarsko-weterynaryjnych (Dz.U. z 2009 r. Nr 93, poz. 767 ze zm. art. 1).

${ }^{8}$ Leczenie jako jedna $z$ form realizacji prawnej ochrony zwierzat w Polsce, http://weterynarianews.pl/leczenie-form-realizacji-prawnej-ochrony-zwierzat-polsce/ (dostęp: 2 kwietnia 2016). 
Pomiędzy zakładami leczniczymi dla zwierząt dochodzi często do ostrej rywalizacji, która ma cechy walki ekonomicznej. Walka ta nie przynosi poprawy standardów jakości usług. Lekarze weterynarii jako przedstawiciele wolnych zawodów zaufania publicznego wykonują swoje usługi w interesie swoich klientów oraz równolegle w interesie publicznym. Występują w podwójnej roli — jako część systemu ochrony prawnej jednostki oraz jako składnik systemu ochrony zdrowia publicznego. Z powodu tej podwójnej funkcji mają prawnie ograniczoną swobodę wykonywania swoich zawodów. Społeczeństwo, zabezpieczając swoje interesy, w tym potrzebę skutecznej ochrony zdrowia publicznego, ustanowiło prawo, które ma być gwarancją, że usługi wyższego rzędu świadczone przez zawody zaufania publicznego wykonywane będą na najwyższym poziomie. Osoby uprawiające zawody zaufania publicznego zobowiązane są z mocy prawa do uczestniczenia w samorządach zawodowych - pochodzących $\mathrm{z}$ wyboru środowiskowych strukturach nadzorujących zgodność postępowania zawodowego swoich członków z zasadami etyki i deontologii obowiązującymi w poszczególnych branżach ${ }^{9}$.

\section{KODEKS ETYKI LEKARZA WETERYNARII}

W mojej ocenie na szczególną uwagę zasługuje Kodeks Etyki Lekarza Weterynarii. Generalnie kodeksy etyki zawodowej powinny być i są tworzone w przypadku określonych profesji - „zawodów zaufania publicznego”, które są predestynowane do służenia ludziom. Wykonywanie ich oparte jest najczęściej na bezpośrednim kontakcie z drugim człowiekiem, w przypadku lekarza weterynarii — z człowiekiem i zwierzęciem. Przedstawiciel zawodu zaufania publicznego ma możliwość wpływania na los drugiej osoby, czy też jak to ma miejsce w przypadku lekarzy weterynarii - na los zwierzęcia. Działalność zawodowa przy realizacji takich zawodów ma wiązać się ze szczególnym narażeniem na zachowania niemoralne. Zawód zaufania publicznego wymaga w dużej mierze spełnienia warunków fachowych i moralnych ${ }^{10}$. Lekarz weterynarii obok wiedzy merytorycznej/ fachowej powinien posiadać również „kręgosłup moralny”, gdyż w jego rękach jest przecież życie i zdrowie zwierząt.

W przypadku zawodu lekarza weterynarii pojawiają się określenia: humanitarny/niehumanitarny. Lekarz weterynarii może być przyzwoity bądź nie, moralny albo zupełnie odstający od ogólnie przyjętych kanonów zachowań. Wachlarz norm etyczno-zawodowych lekarza weterynarii jest bardzo szeroki i rozciąga się

9 B. Fojut-Pałka, Lecznictwo zwierzą - refleksje weterynarza, http://www.medicusveterinarius.pl/?s=artykuly\&a=2 (dostęp: 15 marca 2016).

10 Szeroko na temat zawodów zaufania publicznego i roli kodeksów etyki zawodowej: A. Breczko, Etyka zawodowa radcy prawnego, [w:] Etyka, deontologia, prawo, red. P. Steczkowski, Rzeszów 2008, s. 132-133. 
na obowiązkowe przestrzeganie zasad etyki ogólnoludzkiej oraz zasad dobrych obyczajów, nakazujących dbałość o godność zawodu. Normy etyczne odnoszą się do takich cech, jak: sumienność, rzetelność, uczciwość, kultura osobista i taktowne postępowanie. Lekarza weterynarii, oprócz ustawy o samorządzie i uchwał organów izb, obowiązują przepisy szeroko rozumianego prawa weterynaryjnego. Problem etyczny w wykonywaniu zawodu lekarza weterynarii może stanowić: sterylizacja, eutanazja, eksperymenty na zwierzętach, manipulowanie genotypem, przeszczepy narządów, paternalizm wobec klienta. Jak podkreśla się w literaturze, współcześnie bycie etycznym lekarzem weterynarii nie jest łatwe ${ }^{11}$. Problem ten występuje szczególnie wyraźnie na styku lekarz weterynarii-bezdomne zwierzęta. Kwestia ta powinna być rozpatrywana w dwóch aspektach: prawnym oraz etycznym. Normy prawne powinny uwzględniać te czynniki, które jednoznacznie wskazują, kiedy zwierzęta są narażone na ból i cierpienie, których człowiek kierujący się elementarnymi zasadami etyki nie może tolerować. Innym problemem o wymiarze etycznym jest problem pozbawiania życia istoty żyjącej, jaką jest zwierzę. Wielu ludzi jest zdania, że bezkarnie można zabić np. mysz, szczura, owady czy bakterie, które wywołują choroby. Duży odsetek społeczeństwa uważa, że obowiązki etyczne wobec zwierząt są mniejsze niż wobec ludzi ${ }^{12}$.

Zgodnie z Kodeksem Etyki Lekarza Weterynarii weterynarz składa przyrzeczenie, w którym następuje odwołanie do sumienności, aktualnej wiedzy weterynaryjnej, godności zawodu. Lekarz weterynarii ma się przyczyniać do postępu nauk weterynaryjnych i ma obowiązek dbania o zdrowie zwierząt. Jednakże celem nadrzędnym jest zawsze dobro człowieka. W Kodeksie Etyki Lekarza Weterynarii zostały wymienione cechy, które powinien posiadać weterynarz. Powinien go cechować przyjazny i racjonalny stosunek do zwierząt. W przypadku chorego zwierzęcia należy ograniczać jego cierpienia i dążyć do przywrócenia mu zdrowia. W uzasadnionych przypadkach lekarz weterynarii może rozważyć możliwość humanitarnego uśmiercenia zwierzęcia ${ }^{13}$ (art. 15 Kodeksu Etyki Lekarza Weterynarii ${ }^{14}$ ). Ponadto lekarzowi weterynarii nie wolno narzucać swoich usług. Ma on

${ }^{11}$ Lekarz weterynarii nie może popadać w rutynę. Każdy przypadek jest zupełnie inny i wymaga indywidualnego podejścia oraz pełnego zaangażowania. Zawód lekarza weterynarii jest bardzo ciężkim zawodem, wymagającym bezwzględnego poświęcenia, oddania sprawie i wielu wyrzeczeń — wywiad z lekarzem weterynarii Agatą Przetakiewicz, http://www.stara.strefaminsk.pl/strefanieobojetnych/42-lek-wet-agata-przetakiewicz.html (dostęp: 17 kwietnia 2016).

12 M. Lisiowska et al., Czy łatwo być etycznym lekarzem, będac pracownikiem Inspekcji Weterynaryjnej?, „Życie Weterynaryjne” 87, 2012, nr 7, s. 554-556.

13 Wśród lekarzy weterynarii padają krytyczne uwagi pod adresem Kodeksu, dotyczą one także eutanazji zwierząt. Podkreśla się, że lekarz weterynarii nie jest filozofem, tylko medykiem-praktykiem. Na tle tego zapisu można sformułować pytanie: czy lekarz weterynarii ma prawo wykonywać eutanazję albo wysyłać do uboju z konieczności? W. Szczerbiak, O „Kodeksie”-całkiem prywatnie, http://www.medicusveterinarius.pl/?s=artykuly\&a=209 (dostęp: 4 kwietnia 2016).

${ }^{14} \mathrm{Z}$ realizacją norm wynikających z art. 15 Kodeksu Etyki Lekarza Weterynarii nie zawsze bywa dobrze. W prasie możemy znaleźć przykłady świadczące o naruszaniu tej normy. W „Elblą- 
za zadanie zapewnić ciągłość leczenia, a w razie konieczności wskazać innego lekarza. Lekarz weterynarii ma upowszechniać prawa zwierząt i respektować podstawowe zasady sozologii (art. 30). Powinien wpływać na zapewnienie zwierzętom dobrostanu, przeciwstawiać się niewłaściwym zachowaniom wobec zwierząt. W sytuacji kiedy uczestniczy w doświadczeniach na zwierzętach (art. 33), ma dbać, aby zwierzętom doświadczalnym nie był zadawany nadmierny ból, cierpienie i obrażenia.

Zgodnie z art. 29 Kodeksu lekarz weterynarii ma obowiązek prowadzenia wymaganej prawem dokumentacji, która związana jest $\mathrm{z}$ wykonywaniem zawodu. Może poświadczać dane, co do których posiada wiedzę, kompetencje, kwalifikacje oraz które zostały przez niego sprawdzone. Każde zaświadczenie lub inny dokument powinien umożliwiać identyfikację lekarza weterynarii, który je wystawił.

\section{TAJEMNICA ZAWODOWA LEKARZY WETERYNARII}

Lekarz weterynarii zobowiązany jest do zachowania tajemnicy zawodowej. Obowiązek ten jest prawnie określony w ustawach pragmatycznych regulujących zawód lekarza weterynarii oraz w Kodeksie Etyki Lekarza Weterynarii (art. 28). Czym jest tajemnica zawodowa? Tajemnica zawodowa jako zasada jest obecna we wszystkich współczesnych kodeksach etyki zawodowej lekarzy, prawników. Dotyczy ona także lekarzy weterynarii. Pacjent/właściciel zwierzęcia ma pełne prawo do poszanowania swojej prywatności, lekarz jest natomiast moralnie zobowiązany nie czynić niczego, co mogłoby tę prywatność pogwałcić15.

Właściciel lub opiekun zwierzęcia jest uprawniony do uzyskania informacji o stanie zdrowia zwierzęcia, metodach leczenia, dających się przewidzieć ich skutkach praktycznych, o możliwościach zaniechania leczenia z określonych powodów, przewidywanych kosztach usługi weterynaryjnej. Lekarz weterynarii zobowiązany jest do zachowania $\mathrm{w}$ tajemnicy tych informacji. Zgodnie $\mathrm{z}$ art. 28 Kodeksu, niezależnie od charakteru wykonywanej czynności, lekarza weterynarii obowiązuje tajemnica zawodowa. Zwolnienie z niej może nastąpić bądź za zgodą posiadacza zwierzęcia, bądź w przypadku zagrożenia zdrowia publicznego lub

skim Dzienniku Internetowym” opisano lekarza weterynarii, który nie udzielił przez kilka godzin pomocy psu potrąconemu przez samochód i przywiezionemu przez straż miejską, ponieważ, jak twierdził, nie miał podpisanej umowy z gminą. Tymczasem Kodeks stanowi w art. 15, że „lekarza weterynarii powinien cechować przyjazny i racjonalny stosunek do zwierząt”. Ponadto: „w przypadku chorego zwierzęcia należy ograniczyć jego cierpienia i dążyć do przywrócenia mu zdrowia”. Lekarz weterynarii nie udzielit pomocy psu potraconemu przez samochód, https://info.elblag.pl/31,24620,Lekarz-weterynarii-nie-udzielil-pomocy-psu-potraconemu-przez-samochod.html (dostęp: 11 kwietnia 2016).

15 Szerzej na ten temat: Z. Szawarski, Wprowadzenie — dwa modele etyki medycznej, [w:] W kręgu życia i śmierci. Moralne problemy medycyny współczesnej, red. idem, Warszawa 1987, s. 5-22. 
gdy tego wymaga ustawa. Naruszenie obowiązku zachowania tajemnicy lekarskiej może skutkować odpowiedzialnością cywilną, karną, zawodową i dyscyplinarną. Obowiązek zachowania poufności informacji stanowi w przypadku wszystkich zawodów medycznych normę etyczną wyrażoną wprost w kodeksach deontologicznych. Analogicznie jest w przypadku Kodeksu Etyki Lekarza Weterynarii. Zakres chronionych informacji wyznaczany jest granicami prawa do prywatności bez względu na to, czy czynności lecznicze dotyczą samego pacjenta czy właściciela zwierzęcia. Prywatność podlega samoistnej ochronie prawnej, posiada status prawa podmiotowego $\mathrm{W}$ cywilistycznym ujęciu treści art. 23 k.c. ${ }^{16}$

Jak już wskazano, przedmiot tajemnicy zawodowej obejmuje informacje powiązane z pacjentem, czyli dane właściciela/opiekuna zwierzęcia, dane identyfikacyjne pacjenta właściwego: zwierzę, stado, hodowla, farma, podmiot kontrolowany, które zostały uzyskane w związku z wykonywaniem czynności zawodowych. Informacje, które mogą być powiązane $\mathrm{z}$ wykonywaniem zawodu, ale pozyskane zostały w inny sposób, np. w czasie kontaktów towarzyskich, nie są objęte zakresem tajemnicy zawodowej. Przypomnijmy, iż zakres tajemnicy lekarsko-weterynaryjnej ma charakter absolutny, czyli istnieje całkowity zakaz ujawniania jakichkolwiek informacji uzyskanych w trakcie wykonywania czynności zawodowych. Omówmy teraz bardziej szczegółowo trzy przypadki zwolnienia lekarza weterynarii z obowiązku zachowania tajemnicy.

Po pierwsze, za zgodą właściciela lub opiekuna zwierzęcia (ex voluntas). To właściciel lub opiekun zwierzęcia jest dysponentem informacji o sobie i swoim zwierzęciu i tylko on może udzielić rzeczowej zgody. Zgoda musi być wyrażona przed ujawnieniem informacji w sposób świadomy i niewymuszony. Nie może być powiązana z innymi czynnościami, np. uzyskaniem korzyści w zamian za możliwość zdjęcia z lekarza weterynarii obowiązku zachowania tajemnicy. Przed wyrażeniem zgody weterynarz ma obowiązek poinformować właściciela lub opiekuna zwierzęcia o skutkach ujawnienia tajemnicy i celu jej wykorzystania. Brak pouczenia ze strony lekarza weterynarii może powodować unieważnienie wyrażenia zgody. Dopuszcza się wyrażenie zgody w sposób dorozumiany. Jednakże należy unikać takich okoliczności, starając się, by zgoda miała formę pisemną. Wyrażenie zgody obowiązuje, dopóki dysponent danych jej nie odwoła. Zgoda ma charakter odwołalny.

Po drugie, ujawnienie informacji ze względu na zagrożenie zdrowia publicznego. W wyniku czynności zawodowych podejmowanych przez lekarza weterynarii pozyskanie informacji o sytuacji zagrażającej życiu lub zdrowiu człowieka (np. podejrzenie lub stwierdzenie wścieklizny) oraz występowaniu chorób mogących stanowić szczególne zagrożenie dla populacji zwierząt (np. pryszczyca, wąglik, afrykański pomór świń, gruźlica bydła) powoduje uruchomienie urzędowego

16 Ł.B. Pilarz, Tajemnica lekarska - uwagi prawne lekarza weterynarii, http://weterynarianews.pl/tajemnica-lekarska-uwagi-prawne-lekarza-weterynarii/ (dostęp: 15 lutego 2016). 
postępowania. W takim przypadku bezcelowym, bezsensownym i niemożliwym byłoby utrzymanie w tajemnicy informacji o występujących zagrożeniach. Ujawnienie ich pozwala na podjęcie środków zaradczych.

Po trzecie, ujawnienie tajemnicy wymagane przepisami prawa (ex lege) ustawą o ochronie zdrowia zwierząt oraz zwalczaniu chorób zakaźnych zwierząt (art. 10 k.p.a. $)^{17}$.

\section{USŁUGI WETERYNARYJNE W PRAKTYCE — ODPOWIEDZIALNOŚĆ ODSZKODOWAWCZA LEKARZA WETERYNARII}

Oczywiście, ze świadczoną usługą weterynaryjną bywa różnie. Czasami mimo chęci i najlepszego przygotowania weterynarza zdarzają się błędy w sztuce, może dojść także do powikłań, które wpisane są w ryzyko danego zabiegu czy operacji. Zasady ewentualnej odpowiedzialności za szkodę wyrządzoną przez lekarza weterynarii zasadniczo nie różnią się od zasad odpowiedzialności przy innego rodzaju szkodach. Pewna specyfika zawodu weterynarza i wiążąca się z tym specjalistyczna wiedza, niedostępna dla przeciętnego człowieka, powodują, że odpowiedzialność ta bywa trudna do wyegzekwowania. W medycynie funkcjonuje dynamicznie rozwijająca się gałąź prawa, określana jako prawo medyczne. Diagnozowanie zwierzęcia często, czy nawet najczęściej, odbywa się na podstawie ustnej umowy pomiędzy lekarzem weterynarii a opiekunem zwierzęcia. Przesłanki odpowiedzialności lekarza weterynarii są takie same, jak ogólne zasady odpowiedzialności cywilnej. Zgodnie z art. 361 k.c. zobowiązany do odszkodowania ponosi odpowiedzialność tylko za normalne następstwa działania lub zaniechania, z którego szkoda wynikła. W powyższych granicach, w braku odmiennego przepisu ustawy lub postanowienia umowy, naprawienie szkody obejmuje straty, które poszkodowany poniósł, oraz korzyści, które mógłby osiągnąć, gdyby mu szkody nie wyrządzono. Tym samym lekarz ponosi odpowiedzialność tylko za następstwa swoich działań lub zaniechań, które spowodowały szkodę. Niemożliwe jest pociągnięcie do odpowiedzialności za zdarzenia, które nie stanowią normalnych następstw działań podejmowanych przez weterynarza ${ }^{18}$.

17 R. Karczmarczyk, Etyka zawodowa lekarza weterynarii: tajemnica zawodowa, „Życie Weterynaryjne" 90, 2015, $\mathrm{nr}$ 8, s. 495-496.

18 Ł. Walter, Odpowiedzialność za szkody wyrządzone przez lekarza weterynarii, „Konie i Rumaki” 2013, nr 3, http://www.konieirumaki.pl/pl/odpowiedzialnosc-lekarza-weterynarii (dostęp: 28 marca 2016). 


\section{ODPOWIEDZIALNOŚĆ DYSCYPLINARNA LEKARZA WETERYNARII}

Zgodnie z Ustawą z dnia 21 grudnia 1990 r. o zawodzie lekarza weterynarii i izbach lekarsko-weterynaryjnych członkowie samorządu podlegają odpowiedzialności zawodowej przed sądami lekarsko-weterynaryjnymi za postępowanie sprzeczne z zasadami etyki i deontologii weterynaryjnej oraz za naruszenie przepisów o wykonywaniu zawodu lekarza weterynarii (art. 45). Sąd lekarsko-weterynaryjny może orzekać następujące kary: upomnienie, nagana, zawieszenie prawa wykonywania zawodu lekarza weterynarii na okres od 3 miesięcy do 3 lat, jak też pozbawienie prawa wykonywania zawodu (art. 46.1). Sprawy odpowiedzialności zawodowej lekarzy weterynarii rozpatrują okręgowe sądy lekarsko-weterynaryjne i Krajowy Sąd Lekarsko-Weterynaryjny (art. 50.1). Lekarz weterynarii zawieszony w prawie wykonywania zawodu nie może wykonywać zawodu w żadnej formie (art. 51.2). W sprawach spornych pomiędzy właścicielem/opiekunem zwierzęcia a lekarzem weterynarii rzecznik przesłuchuje właściciela/opiekuna i personel lecznicy, który w tym czasie zajmował się chorym zwierzęciem. Od weterynarza można domagać się zwrotu kosztów leczenia, ale tylko w postępowaniu cywilnym. Wyrok sądu koleżeńskiego jest wiążący dla sądu cywilnego. Czasem właściciele/opiekunowie zakładają obie sprawy równolegle. Sąd cywilny z reguły czeka na ustalenia izby lekarskiej ${ }^{19}$. Zgodnie z orzeczeniem Trybunału Konstytucyjnego każdy powinien móc się odwołać do sądu od kary dyscyplinarnej, niezależnie od tego, czy wykonuje zawód zaufania publicznego i jak został ukarany (sygn. akt SK 10/13). Prawo do sądu powinno być zagwarantowane w ramach każdego postępowania dyscyplinarnego. Kara dyscyplinarna ma charakter represyjny, jest szczególnie dolegliwa dla osób wykonujących zawody zaufania publicznego, do których są zaliczani lekarze weterynarii. Kara dyscyplinarna może narażać i w naszym mniemaniu naraża na utratę zaufania oraz dyskredytuje w oczach opinii publicznej ${ }^{20}$. Co więcej, Trybunał Konstytucyjny eksponuje pogląd, że zasady deontologiczne nie są normami prawnymi, lecz normami autonomicznymi w stosunku do norm prawnych. To normy prawne powinny posiadać legitymację aksjologiczną, normy etyczne nie potrzebują legitymacji jurydycznej. Wszystkim demokratycznym systemom prawnym wspólna jest ogólna formuła deliktu (przewinienia) zawodowego, nieograniczona do naruszenia przepisów prawa pozytywnego. Nie ogranicza się ona do niezgodności zachowań z określonym przepisem ustawy ani do naruszenia określonych przepisów zebranych w kodeksie etyki zawodowej określonej grupy zawodowej, ani też do określonej formy

19 M. Sas, Rozmowa z dr n. wet. Wojciechem Hildebrandem, Dolnoślaska Izba Lekarsko-Weterynaryjna. Wet na cenzurowanym, www.psy.pl/art5952 (dostęp: 31 marca 2016).

${ }_{20}$ TK: każdy powinien móc odwołać się od kary dyscyplinarnej, http://www.rp.pl/artykul/1053464-TK--kazdy-powinien-moc-odwolac-sie-od-kary-dyscyplinarnej.html (dostęp: 14 marca 2016). 
wyrazu zasad deontologicznych. Regułą jest też brak ustawowej lub sądowej definicji „przewinienia zawodowego”, wynikający z założenia, że o przewinieniu wypowiadają się profesjonaliści, którzy z własnego doświadczenia i ogólnej kompetencji czerpią wiedzę o tym, czy zachowanie było prawidłowe. Założenie to nie jest kwestionowane w orzecznictwie Europejskiego Trybunału Praw Człowieka. Istotnym elementem samoregulacji jest właśnie ustalenie obowiązujących zasad deontologicznych bądź to w formie kodeksów, bądź orzeczeń wydawanych $\mathrm{w}$ indywidualnych sprawach czy też doradztwa w indywidualnych sprawach. Nie ma przeszkód, ażeby norma deontologiczna, której naruszenie uzasadnia odpowiedzialność zawodową, była rekonstruowana np. z przyrzeczenia lekarskiego lekarzy weterynarii albo z wcześniejszych wypowiedzi sądów zawodowych ${ }^{21}$.

Zgodnie z treścią Rozporządzenia Ministra Rolnictwa i Gospodarki Żywnościowej z dnia 29 lipca 1993 r. w sprawie postępowania dotyczącego odpowiedzialności zawodowej lekarzy weterynarii istnieje możliwość powołania biegłego przez lekarza weterynarii, którego dotyczy postępowanie wyjaśniające. Biegłego może powołać też obwiniony lekarz weterynarii. Również rzecznik odpowiedzialności zawodowej oraz sąd lekarsko-weterynaryjny mogą korzystać z wiedzy specjalistycznej biegłych, jeżeli jest ona niezbędna do rozstrzygnięcia sprawy. W toku postępowania wyjaśniającego rzecznik odpowiedzialności zawodowej powinien dążyć do szczegółowego wyjaśnienia rozpatrywanej sprawy. W tym celu może on przesłuchać lekarza weterynarii, którego dotyczy postępowanie, świadków, biegłych, jak również przeprowadzić inne dowody. Lekarz weterynarii, którego dotyczy postępowanie wyjaśniające, może zgłaszać wnioski dotyczące m.in. powoływania biegłych. Jednakże niekorzystanie przez lekarza weterynarii z takiej możliwości nie ma bezpośredniego wpływu na prowadzone postępowanie wyjaśniające. Przepisy dotyczące odpowiedzialności zawodowej lekarzy weterynarii dopuszczają, aby rzecznik odpowiedzialności zawodowej, wnosząc wniosek o ukaranie lekarza weterynarii do właściwego sądu lekarsko-weterynaryjnego, wskazał w nim jako dowód w danej sprawie konieczność przeprowadzenia dowodu z opinii biegłego lekarza weterynarii. Sąd lekarsko-weterynaryjny jest zobowiązany dążyć do wszechstronnego zbadania wszystkich okoliczności sprawy. Stąd może dopuszczać z urzędu wszelkie dowody. Biegli lekarze weterynarii powoływani są w przedmiocie odpowiedzialności zawodowej lekarzy weterynarii do konkretnej sprawy. W przypadku spraw, które dotyczą, dla przykładu, błędów w sztuce leczenia zwierząt, rolą biegłego jest bezstronne przekazanie organowi procesowemu stanu aktualnej wiedzy medyczno-weterynaryjnej związanej z rozpatrywaną sprawą. Biegłym lekarzem weterynarii powinna być osoba, która cieszy się dużym autorytetem w środowisku zawodowym ${ }^{22}$.

21 L. Bosek, W sprawie senackiego projektu ustawy o zmianie ustawy Prawo łowieckie, „Przegląd Sejmowy" 123, 2014, nr 4, s. 169.

22 P. Listos, Odpowiedzialność zawodowa lekarza. Lekarz weterynarii jako biegty w postępowaniu dotyczacym odpowiedzialności zawodowej, „Weterynaria w Praktyce” 2011, nr 5, s. 86. 
Lekarze weterynarii powoływani są na biegłych w sprawach cywilnych i karnych w związku z działalnością służby weterynaryjnej. W odniesieniu do realizacji umów sprzedaży zwierząt zadaniem biegłego jest najczęściej ustalić w drodze oględzin, na jaką chorobę zakupione zwierzę choruje, lub na podstawie akt sprawy — na jaką chorobę chorowało. Biegły musi ustalić, czy zwierzę było już chore u sprzedawcy, z wykluczeniem możliwości, dla przykładu, zarażenia się u kupującego. Opinia biegłego lekarza weterynarii może dotyczyć zagadnień związanych z płodnością zwierzęcia, pochodzenia od określonych rozpłodników, określonych cech rodziców zwierząt kupionych. Sądy kierują najczęściej pod adresem biegłego odpowiednie pytania, mające na celu ustalenie, czy przy leczeniu zwierzęcia zachowana była przez pracowników służby weterynaryjnej należyta staranność. Jeżeli nie było owej staranności, sąd może chcieć ustalić, czy przy jej zachowaniu istniały i w jakim zakresie w poszczególnych stadiach rozwoju choroby szanse na utrzymanie zwierzęcia przy życiu ${ }^{23}$.

\section{PODSUMOWANIE}

Z uwagi na fakt, iż współcześnie zawód lekarza weterynarii jest dość popularny, etyka tego zawodu ma coraz większe znaczenie. Etyka zawodowa w weterynarii jest podobna do etyki zawodu lekarza nauk medycznych. Zarówno lekarz weterynarii, jak i lekarz nauk medycznych są zobowiązani do niesienia pomocy potrzebującym. W przypadku lekarza weterynarii potrzebującym jest zwierzę, którego status moralny i sytuacja prawna nie jest do końca ustalona. Zwierzę jest zależne od człowieka, wobec tego deontologia weterynaryjna może pomóc w zabezpieczeniu dobra zwierzęcia.

\section{THE ROLE OF THE VETERINARY DEONTOLOGY IN THE PROTECTION OF ANIMALS AND THEIR RIGHTS}

Summary

Due to the fact that today the profession of a veterinary surgeon is quite popular, the ethics of the profession is becoming increasingly important. Professional ethics in veterinary medicine is similar to the ethics of the medical profession of medical sciences. Both the veterinarian and a doctor of medical sciences are committed to help the needy. If a veterinarian meets an animal in need, whose moral status and the legal situation is not entirely fixed, it is dependent on a man, and the veterinary deontology can help in securing good animal.

23 A. Grudzień, Okoliczności występowania lekarza weterynarii jako biegłego, www. veterynaria.pl/articles.php?id=203 (dostęp: 16 kwietnia 2016). 